\title{
MECHANISM OF AN EPIBIONT BURDEN: CREPIDULA FORNICATA INCREASES BYSSUS THREAD PRODUGTION BY MTTILUS EDULIS
}

\author{
DAVID W. THIELTGES AND GHRISTIAN BUSGHBAUM
}

Alfred Wegener Institute for Polar and Marine Research, Wadden Sea Station Sylt, Hafenstrasse 43, 25992 List, Germany

(Received 12 January 2006; accepted 21 November 2006)

\begin{abstract}
Epibionts of mussels can have detrimental effects on their basibionts, such as reduced growth rates, lower fecundity, increased mortality and an enhanced risk of dislodgement of the overgrown bivalves due to stronger hydrodynamic forces. In blue mussels Mytilus edulis, the epibiotic American slipper limpet Crepidula fornicata reduces growth and survival. In a field experiment we tested the hypothesis that an enhanced byssus thread production with high energetic costs for the mussels due slipper limpet epibionts is the underlying mechanism for the epibiont burden. Byssus thread production in overgrown mussels was twice as high as in unfouled $M$. edulis $(11 \pm 0.9$ and $5.4 \pm 0.6$ byssus threads $/ \mathrm{mussel} /$ day, respectively). A control experiment revealed intermediate byssus thread production $(8.4 \pm 0.8$ byssus threads/mussel/day) in mussels cleaned of $C$. fornicata at the beginning of the experiments, indicating that C. fornicata is responsible for the effects observed. We conclude that increased byssus production in fouled $M$. edulis is a functional response to higher drag caused by epibionts and that it is associated with increased energy expenditure that reduces allocation of resources for other processes such as growth, reproduction and survival. Such indirect effects of epibionts, mediated by an enhanced byssus production, may be widespread in byssus-producing bivalves, with important implications for their population dynamics.
\end{abstract}

\section{INTRODUGTION}

Marine epibenthic molluscs are commonly overgrown with a rich epifauna and epiflora, a phenomenon called epibiosis (Wahl, 1989). The associated epibionts can be beneficial for the overgrown organisms by e.g. reducing predation pressure on the basibionts (Wahl \& Hay, 1995; Thieltges, 2005a). However, epibionts are often also a burden for their basibionts. In littorinid gastropods for example, barnacle epibionts increase snail mortality, reduce fecundity and lower crawling speed due to the additional weight individual snails have to carry (Buschbaum \& Reise, 1999). Hence, epibonts may play an important role in population dynamics of overgrown molluscs.

In blue mussels (Mytilus edulis L.), a common bivalve of northeastern Atlantic shores, an important ebibiont with negative effects on the mussel basibiont is the American slipper limpet Crepidula fornicata (L.) (Fig. 1). In the northern part of its European distribution, this gastropod lives in stacks of conspecifics, with the bottommost individual of a stack predominantly being attached to a living blue mussel (Thieltges, Strasser \& Reise, 2003). Mussels with C. fornicata epigrowth show a strongly reduced growth rate and a significantly higher mortality compared to unfouled mussels, as inferred from field experiments (Thieltges, 2005b). Although C. fornicata is a filter feeder, suggesting trophic competition with the basibionts to be the mechanism involved, field experiments did not support this (Thieltges, 2005b).

An alternative mechanism may be that the observed epibiont burden is the result of an enhanced byssus thread production in the mussels with subsequent detrimental effects: the stacks of C. fornicata protruding into the water column cause stronger hydrodynamic forces for the basibionts, which compel the mussels to spend more energy on byssus production to prevent dislodgement. This increased energy demand may subsequently lead to

Correspondence: D.W. Thieltges; e-mail: dthieltges@yahoo.com the observed negative effects on mussel growth and survival. We tested this hypothesis in a field experiment.

\section{MATERIAL AND METHODS}

Mussels Mytilus edulis of $55-65 \mathrm{~mm}$ in shell length were randomly collected on a mussel bed near the island of Sylt in the northern Waddden Sea (North Sea, Germany, Fig. 2). Sixty mussels were overgrown with stacks of three to five Crepidula fornicata and 30 mussels were without any natural epibionts. In 30 of the $C$. fornicata-overgrown mussels, the limpet epibionts were carefully removed. All mussels were singly placed in small cages made of polypropylene mesh (mesh size $5 \mathrm{~mm}$ ). Cage size was $10 \mathrm{~cm}$ in diameter and $10 \mathrm{~cm}$ in height and they were individually mounted on wooden boards. These boards were fixed with rods on the uppermost mussel layer on the same mussel bed in a completely randomized design with cages approximately $50 \mathrm{~cm}$ apart. At the beginning of the experiment, the byssus threads of each mussel were carefully removed with a scalpel. After two tides $(24 \mathrm{~h})$, the number of byssus threads produced by each mussel was counted in the field.

Data were analysed using a one-factorial ANOVA design, with epibiont treatment (unfouled, fouled and limpets taken off) as fixed factor. Since visual inspection and the Cochran test revealed a data set with homogenous variances and normal distributions, nontransformed data were used for the analysis. Posthoc calculations were done with Tukey's HSD-test for unbalanced data sets (Spjotvoll/Stoline) (Day \& Quinn, 1989).

\section{RESULTS}

There was a significant difference in the number of byssus threads produced between the three treatments (ANOVA; $F_{2,81}=12.8, P<0.001$ ) (Fig. 3). Mussels with Crepidula fornicata epibionts (11.0 \pm 0.9 byssus threads/mussel/day) produced 


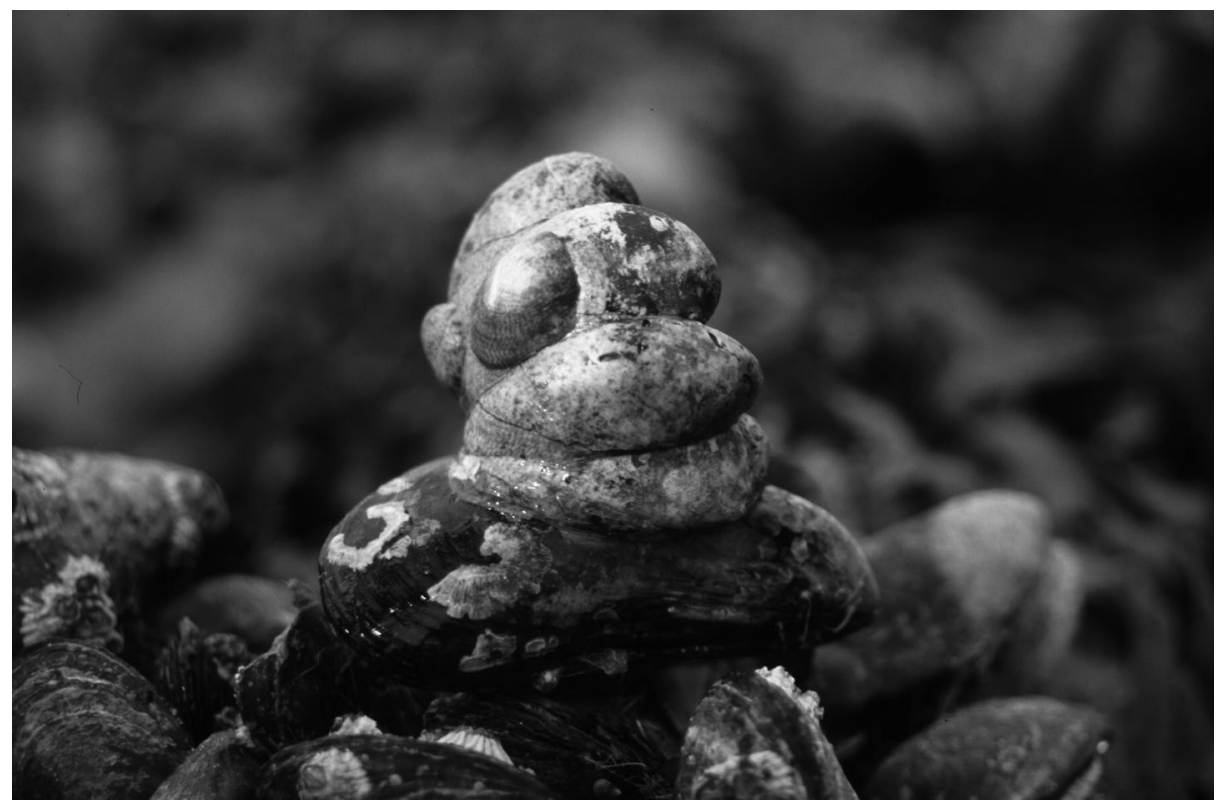

Figure 1. Stack of slipper limpets Crepidula fornicata on a blue mussel Mytilus edulis on a mussel bed.

more than twice as much byssus threads as unfouled mussels $(5.4 \pm 0.6$ byssus threads/mussel/day) with the difference being statistically significant (Tukey HSD-test for unbalanced sample sizes; $P<0.001$ ). Mussels from which $C$. fornicata had been removed at the beginning of the experiment produced intermediate numbers of byssus threads $8.4 \pm 0.8$ byssus threads/mussel/day). The difference from the mussels with C. fornicata was significant (Tukey HSD-test for unbalanced



Figure 2. Tidal flats of the northern part of the island of Sylt with mussel beds (dotted). Mussel sampling and experiments were performed on a mussel bed located at the mouth of a tidal channel (black circle). 


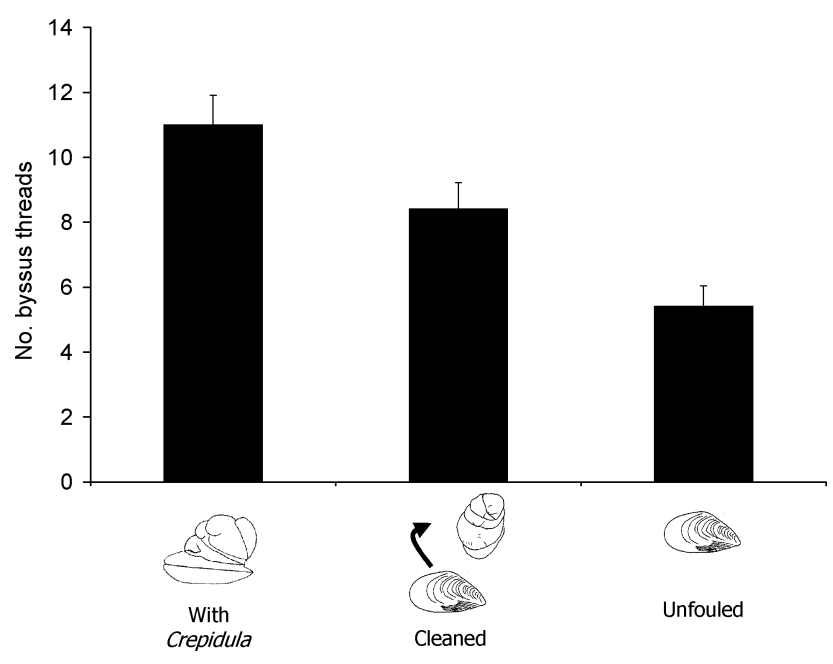

Figure 3. Mean number of byssus threads $(+$ standard error) produced by blue mussels Mytilus edulis in a field experiment with mussels overgrown with Crepidula fornicata ('with Crepidula'), mussels where C. fornicata was removed ('cleaned') and mussel without any natural epibionts ('unfouled'). $n=27-29$.

sample sizes; $P=0.03)$ and from the unfouled Mytilus edulis marginally significant (Tukey HSD-test for unbalanced sample sizes; $P=0.06)$.

\section{DISCUSSION}

Crepidula fornicata epibionts induced a higher byssus thread production in overgrown blue mussels compared to unfouled mussels. Previous studies showed that byssus-producing mussels appear capable of perceiving hydrodynamic forces, since mussels adjust the rate of byssus production to current velocities or to agitation frequency (Young, 1985; Clarke \& McMahon, 1996; Rajagopal et al., 1996). Hence, the higher byssus production in mussel individuals with $C$. fornicata overgrowth indicates stronger forces acting on individuals carrying epibionts. These increased forces result from changes in hydrodynamics due to $C$. fornicata stacks protruding into the water column. To prevent dislodgement, mussels with epibionts have to produce more byssus threads than their unfouled conspecifics. As a result, mussels with $C$. fornicata epibionts have to expend a higher proportion of their metabolic energy on byssus thread production than unfouled mussels. Byssus thread production is a highly energy demanding process (Okamura, 1986) and when this energy diversion exceeds a critical rate, mussels may suffer from the negative effects observed in field experiments, such as reduced growth and survival (Thieltges, 2005b).

The lower byssus thread production in mussels where $C$. fornicata was removed, compared to mussels with epibionts, indicates that slipper limpets are responsible for the observed effect. However, these mussels still produced a higher number of byssus threads than unfouled mussels. The time during two tidal cycles may have been too short for the mussels to adjust their byssus production by the byssus gland to the new conditions.

An increase in byssus thread production to prevent dislodgement when fouled with epibionts may also be the mechanism for negative effects on basibionts in other epibiont-mussel associations. For example, barnacle epibionts have been observed to reduce growth in blue mussels (Buschbaum \& Saier, 2001). Since these field experiments did not indicate any trophic competition between mussels and barnacles, an increase in byssus thread production with subsequent growth effects may be the likely mechanism for the observed effects. Such indirect effects of epibionts, mediated by effects on byssus thread production, may also be at work in other byssus-producing bivalves. Since they affect an energetically costly part of the bivalves metabolism, byssus-mediated indirect effects may sometimes be more important for bivalve population dynamics than other effects of epibionts like trophic competition.

\section{REFERENCES}

BUSCHBAUM, C. \& REISE, K. 1999. Effects of barnacle epibionts on the periwinkle Littorina littorea (L.). Helgoland Marine Research, 53: $56-61$.

BUSCHBAUM, C. \& SAIER, B. 2001. Growth of the mussel Mytilus edulis L. in the Wadden Sea affected by tidal emergence and barnacle epibionts. Fournal of Sea Research, 45: 27-36.

CLARKE, M. \& McMAHON, R.F. 1996. Effects of current velocity on byssal-thread production by the freshwater mussel, Dreissenia polymorpha. Canadian Fournal of Zoology, 74: 63-69.

DAY, R.W. \& QUINN, G.P. 1989. Comparisons of treatments after an analysis of variance in ecology. Ecological Monographs, 59: 433-463.

OKAMURA, B. 1986. Group living and the effects of spatial position in aggregations of Mytilus edulis. Oecologia, 69: 341-347.

RAJAGOPAL, S., VAN DER VELDE, G., JENNER, H.A., VAN DER GAAG, M. \& KEMPERS, A.J. 1996. Effects of temperature, salinity and agitation on byssus thread formation of zebra mussel Dreissenia polymorpha. Netherlands Fournal of Aquatic Ecology, 30: 187-195.

THIELTGES, D.W. 2005a. Benefit from an invader: American slipper limpet Crepidula fornicata reduces star fish predation on basibiont European mussels. Hydrobiologia, 541: 241-244.

THIELTGES, D.W. 2005b. Impact of an invader: epizootic American slipper limpet Crepidula fornicata reduces survival and growth in European mussels. Marine Ecology Progress Series, 286: 13-19.

THieltGes, D.W., STRASSER, M. \& REISE, K. 2003. The American slipper limpet Crepidula fornicata (L.) in the northern Wadden Sea 70 years after its introduction. Helgoland Marine Research, 57: 27-33.

WAHL, M. 1989. Marine ebibiosis. I. Fouling and antifouling: some basic aspects. Marine Ecology Progress Series, 58: 175-189.

WAHL, M. \& HAY, M. 1995. Associated resistance and shared doom: effects of epibiosis on herbivory. Oecologia, 102: 329-340.

YOUNG, G.A. 1985. Byssus thread formation by the mussel Mytilus edulis: effects of environmental factors. Marine Ecology Progress Series, 24: 261-271. 